\title{
EFFICIENCY OF THREE NATURAL PRODUCTS FOR CONTROLING DESERT LOCUST, SCHISTOCERCA GREGARIA (FORSK.) (ORTHOPTERA: ACRIDIDAE)
}

\author{
Ali, M. K. ${ }^{(1)}$; Sedik, M. Z. ${ }^{(2)}$; Hosny, A. H. ${ }^{(3)}$ \\ and EL Atreby, Rada, W. M. ${ }^{(1)}$
}

1) Dept. of Plant Disease, Faculty of Agriculture, Ain Shams University

2) Dept. of Plant Microbiology, Faculty of Agriculture, Cairo University

3) General Dept. for Locust and Agro-aviation Affairs, Ministry of agriculture.

\begin{abstract}
Desert locust, Schistocerca gregaria is serious agricultural pest that cause considerable damage to food crops and pasture grasses, particularly during outbreaks.

In this study, laboratory trials and field trials were carried out at different periods in some places in Egypt considered as favorable breeding sites to test its efficacy on the target pests under the Egyptian Agro-Ecosystem to evaluate the performance of three natural products as bio-insecticides, actinomycetes-bacteria, Saccharopolyspora spinosa (Spinosad, Tracer 24\% SC), fungus, Metarhizium anisopliae var. acridium (Green Muscle), and Bacillus thuringiensis-bacteria (Protecto 9.4\%WP).

Results of laboratory trials revealed that, actinomycetes (Spinosad, Tracer $24 \%$ SC) was successful as bio-agent to control both locusts and grasshoppers. Also, fungus M. anisopliae var. acridium (Green Muscle) is promising for locust and grasshoppers control. While the obtained results demonstrated B. thuringiensis (Protecto 9.4\%WP) was not effective on the desert locust, $\mathrm{S}$. gregaria or the grasshoppers.

In the field, (Spinosad, Tracer $24 \% \mathrm{SC}$ ) at concentration of $65 \mathrm{ml} / 100 \mathrm{~L}$ caused $75 \%$ mortality among S. gregaria nymphs after $24 \mathrm{hr}$., reached its maximum effect (100\%) mortality after $48 \mathrm{hr}$. under the Egyptian conditions, while fungus M. anisopliae var. acridium (Green Muscle®) was very slow acting as a bio-control agent when applied against S. gregaria and some acridid pests, but it was safe to non-target organisms and mammals. 50g/ha
\end{abstract}


dose (diluted in diesel) resulted in an optimal mortality of locusts during 21 days, followed by $50 \mathrm{~g} /$ ha dose (diluted in vegetable oil), respectively.

Key words: Acrididae, Locust, Schistocerca gregaria, Biological Control. Metarhizium anisopliae var. acridium, Green Muscle, Spinosad, Bacillus thuringiensis

\section{INTRODUCTION}

The insect pests which belong to family "Acrididae" specially the desert locust, Schistocerca gregaria (Forsk.) and several species of grasshoppers are consider the most serious pests around the world. Locusts can cause considerable economic problems on affected countries and so on grasshoppers on the regional levels (Bullen 1970). So indicated that, instead of waiting for Schistocerca gregaria outbreaks to occur, preventive action against this pest must be taken to prevent its damage (Krall 1995).

The principal aim of strategies for locust controls were designed on: a) reduce the size of the total population of insects, not only to attack insects on crops by insecticides. where that, is the only way now to achieve crop protection and prevent the damages; b) prevent of any plagues may forming by controlling of bands and swarms in affected areas (Steedman, 1990).

The numerous of pesticides used for control during upsurges and plagues caused environmental risks and affected non-target organisms. Due to the environmental and pest-resistance problems associated with chemical pesticides, now there is an increasing interest for the exploitation of biological control agents, available as commercial products or those still under development. Consequently, the environmental pollution by chemical pesticides such as; toxicity to non-target organisms (Tingle, 1996) and humans (Pretty, 1996) has led to new strategies and development of 
environmental friendly alternatives to control locusts and grasshoppers based on microbial control agents (Johnson and Goettel, 1993; Lomer et al., 2001 and Lange, 2005).

At last years the quality of the environment has become a major issue. Many chemicals (pesticides) previously accepted for locust control at national and international levels would not survive the rigorous environmental testing required of modern insecticides. Detailed field assessments are urgently needed to ascertain the impact of all insecticides.

So, the present study is an attempt through laboratory and field trails to evaluate the efficacy of bio-insecticide produces such as a actinomycetesbacteria (Spinosad, Tracer $24 \% \mathrm{SC}$ ), fungus, M. anisopliae var. acridium (Green Muscle) and Bacteria, B. thuringiensis (Protecto 9.4\%WP) against desert locust, S. gregaria under the Egyptian environment conditions.

\section{MATERIALS AND METHODS}

1.1. Experimental insects: During December 2014, locusts preliminary surveys were carried out several times in some places which are considered favorable breeding sites for the desert locust. Such sites may expect to have risks after rains fell during October and November 2014. Small-scale breeding occurred in some places along both sides of Lake Nasser (South of Aswan City) and Abu-Ramad region (Red Sea Coast, near Elba Mountains and Egyptian-Sudanese border) some of desert locust insects and 4th nymphal instars were collected as a parents and kept under gregarious and crowded conditions in cages in the breading room at the Egyptian Locust and Grasshopper Research Dep., Plant Protection Research Institute, following the technique described by Hunter, 1961. 
Desert locust, S. gregaria 4th nymphal instars and adults were used in the laboratory bioassay of the natural products, actinomycetes (Spinosad, Tracer 24\%SC), fungus, M. anisopliae var. acridium (Green Muscle), and B. thuringiensis (Protecto 9.4\%WP).

1.2. Laboratory Bioassay: Spinosad (Tracer $24 \%$ SC) and B. thuringiensis (Protecto 9.4\%WP) were bought as a commercial products, but M. anisopliae var. acridium (Green Muscle) it was kindly provided by the General Department for Locusts and Agro-Aviation Affairs, Egyptian Ministry of Agriculture in co-operation with FAO from the Biological Control Products of South Africa (Pty) Ltd.

This products used to evaluate the biological control against the desert locust, S. gregaria.

Preliminary tests were carried out in the laboratory to determine the dose effect of Spinosad, M. anisopliae var. acridium, and B. thuringiensis on 4th instars and adults of desert locust, S. gregaria. Several concentrations were used of each product, in each concentration 3 replicates were used, each replicate consists of 20 insects. Insects were fed on dipped leaves of (clover/maize) in the different concentrations of Spinosad, Metarhizium and Bacillus. After dipping the leaves for five minutes, the treated leaves were allowed to dry before offering to the insects. After feeding for 24 hours on the treated leaves, normal diet was offered and insects were examined daily for mortality or survive and data recoded. 
Spinosad (Tracer 24\%SC) concentrations were $35,45,65 \mathrm{ml} / 100 \mathrm{~L}$ water, while concentrations of Metarhizium (Green Muscle) were 25gm, 50gm (diluted of oil), 25gm, 50gm (diluted of Diesel) and concentrations of Bacillus (Protecto 9.4\%WP) were 50, 100, 150, 200, 250, 300ml/100L water.

2. Field trail: in the field spinosad (Tracer $24 \%$ SC) at $65 \mathrm{ml} / 100 \mathrm{~L}$ water, Green Muscle 50gr. /ha. Were used. Three blots were determined each blot (1050m2) by using microner AU 8000.

3. Statistical analysis: Data were analyzed by analysis of variance (ANOVA) means, within row, bearing different subscripts are significantly different $(\mathrm{P}<0.05)$.

\section{RESULTS AND DISCUSSION}

1) Laboratory trail: In this trial, Spinosad concentrations used against desert locust were 35,45 and $65 \mathrm{ml} / 100 \mathrm{~L}$ water.

Table (1) shows the mortality percentages of desert locust individuals after treatments with spinosad. It is clear that, spinosad at the highest concentration $(65 \mathrm{ml} / 100 \mathrm{~L}$ water $)$ was almost similar to the chemical pesticide in its effectiveness against desert locust. Where spinosad at high concentration caused $75 \%$ after $24 \mathrm{hr}$. then $85 \%$ after $36 \mathrm{hr}$. and $95 \%$ after $42 \mathrm{hr}$., and finally reached $100 \%$ after $48 \mathrm{hr}$.

Table (2) shows the effect of Green Muscle® on mortality percentage of locust. Data in this table indicate that the efficacy percentages of the fungus on locust population were $8.4,41.2$ and $60.8 \%$ post treatment with $25 \mathrm{~g} / \mathrm{ha}$ diluted in vegetable oil and were 14.7, 54.2 and $77.3 \%$ after treatment with 
$25 \mathrm{~g} / \mathrm{ha}$ diluted in diesel, in the $1 \mathrm{st}, 2 \mathrm{nd}$ and $3 \mathrm{rd}$ weeks post treatment, respectively.

Meanwhile, the efficacy percentages were 19.2, 58.6 and $86.5 \%$ after treatment with 50g/ha diluted with vegetable oil and were 24.7, 65.2 and 94.4\% after treatment with 50g/ha diluted in diesel in the 1st, 2nd and 3rd weeks post treatment, respectively. Highest mortality was recorded for desert locust nymphs.

Table (1): Efficacy of S. spinosa (Spinosad-Tracer 24\%SC) against desert locust, Schistocerca gregaria under laboratory condition.

\begin{tabular}{|c|c|c|c|c|c|}
\hline \multirow{2}{*}{ Stage } & \multirow{2}{*}{ Con. } & \multicolumn{4}{|c|}{ Mortality Percentage \% after: } \\
\cline { 2 - 6 } & & $\mathbf{1 2}$ day & $\mathbf{2 4}$ day & 36 day & 48 day \\
\hline \hline \multirow{3}{*}{$\begin{array}{c}\text { Nymphal } \\
\text { instar }\end{array}$} & $35 \%$ & 20 & 30 & 45 & 65 \\
\cline { 2 - 6 } & $45 \%$ & 35 & 55 & 60 & 75 \\
\cline { 2 - 6 } & $65 \%$ & 40 & 75 & 85 & 100 \\
\cline { 2 - 6 } & control & 0 & 0 & 0 & 0 \\
\hline \multirow{4}{*}{ Adult } & $35 \%$ & 16 & 26 & 42 & 63 \\
\cline { 2 - 6 } & $45 \%$ & 31 & 49 & 55 & 69 \\
\cline { 2 - 6 } & $65 \%$ & 38 & 70 & 80 & 96 \\
\cline { 2 - 6 } & control & 0 & 0 & 0 & 0 \\
\hline
\end{tabular}


Table (2): Efficacy of M. anisopliae var. acridium (Green Muscle®) against desert locust, Schistocerca gregaria under laboratory condition.

\begin{tabular}{|c|c|c|c|c|}
\hline \multirow{2}{*}{ Stage } & \multirow{2}{*}{ Con. } & \multicolumn{3}{|c|}{ Mortality Percentage \% after: } \\
\hline & & 1stweek & 2ndweek & 3rdweek \\
\hline \multirow{5}{*}{$\begin{array}{l}\text { 4th Nymphal } \\
\text { instar }\end{array}$} & $25 \mathrm{~g} \mathrm{V.} \mathrm{Oil} \mathrm{diluted}$ & 8.4 & 41.2 & 60.8 \\
\hline & $25 \mathrm{~g}$ Diesel diluted & 14.7 & 54.2 & 77.35 \\
\hline & 50g V. Oil diluted & 19.2 & 58.6 & 86.5 \\
\hline & 50g Diesel diluted & 24.7 & 65.2 & 94.4 \\
\hline & Control & 0 & 10 & 15 \\
\hline \multirow{5}{*}{ Adult } & 25g V. Oil diluted & 7 & 39 & 55.5 \\
\hline & 25g Diesel diluted & 13.2 & 51.8 & 74.9 \\
\hline & 50g V. Oil diluted & 17.1 & 52.8 & 83.7 \\
\hline & 50g Diesel diluted & 23.0 & 62.0 & 91.6 \\
\hline & Control & 0 & 7 & 11 \\
\hline
\end{tabular}

2. Field trail: Table (3) shows spinosad (Tracer $24 \% \mathrm{SC}$ ) at concentration of $65 \mathrm{ml} / 100 \mathrm{~L}$ caused $70 \%$ mortality among S. gregaria nymphs after $24 \mathrm{hr}$., that reached $95 \%$ after $48 \mathrm{hr}$. So, Spinosad proved that it successful bio insecticide for locust.

Also, the fungus M. anisopliae var. acridium (Green Muscle) at concentration 50g/ha. Diluted in diesel oil and vegetable oil caused 81 and 89 $\%$ after 21 days of treatment. While, the laboratory tests of B. thuringiensis (Protecto 9.4\%WP) showed that, there is no any significant effects against locusts. 
Table (3): Efficacy of S. spinosa (Spinosad-Tracer 24\%SC) and Green muscle against desert locust, Schistocerca gregaria in Sharq ElOwainat region during Marsh 2015.

\begin{tabular}{|c|c|c|c|c|c|c|c|c|c|c|c|}
\hline \multirow{3}{*}{$\begin{array}{c}\text { Treatment } \\
\text { Period }\end{array}$} & \multicolumn{6}{|c|}{ Green Muscle } & \multicolumn{4}{|c|}{ Spinosad $65 \mathrm{ml} / 100 \mathrm{~L}$} & \multirow{3}{*}{ Control } \\
\hline & \multicolumn{3}{|c|}{ 50g V. Oil diluted } & \multicolumn{3}{|c|}{ 50g Diesel diluted } & \multirow[b]{2}{*}{$\begin{array}{c}12 \\
\text { day }\end{array}$} & \multirow[b]{2}{*}{$\begin{array}{c}24 \\
\text { day }\end{array}$} & \multirow[b]{2}{*}{$\begin{array}{c}36 \\
\text { day }\end{array}$} & \multirow[b]{2}{*}{$\begin{array}{c}48 \\
\text { day }\end{array}$} & \\
\hline & $\begin{array}{c}\mathrm{l}^{\text {st }} \\
\text { week }\end{array}$ & $\begin{array}{c}2^{\text {nd }} \\
\text { week }\end{array}$ & $\begin{array}{c}3^{\text {rd }} \\
\text { week }\end{array}$ & $\begin{array}{c}\mathrm{l}^{\text {st }} \\
\text { week }\end{array}$ & $\begin{array}{c}2^{\text {nd }} \\
\text { week }\end{array}$ & $\begin{array}{c}3^{\text {rd }} \\
\text { week }\end{array}$ & & & & & \\
\hline $\begin{array}{c}\text { Mortality } \\
\text { Percentage }\end{array}$ & 16 & 45 & 75 & 20 & 55 & 82 & 35 & 64 & 75 & 89 & 0 \\
\hline
\end{tabular}

Fungal growth on cadavers of insects was evident in the treatments with (Green Muscle®). 50g/ha occurred amongst days 12-13 onwards, while with 25g/ha, it occurred amongst days 15-16 onwards in all cages. Moreover, numbers of dead infected increase slowly and the majorities of the treated locust were much less active than the untreated ones (control treatment).

Analysis of variances of the obtained data showed significant differences among all treatments. Lowest mean of insects number affected was in all treatments with $25 \mathrm{~g} /$ ha diluted i vegetable oil. While, highest one was in all treatments of $50 \mathrm{~g} / \mathrm{ha}$ diluted in diesel. The data convergent approximately in most of the treatments with $25 \mathrm{~g} / \mathrm{ha}$ diluted in diesel and the treatments of $50 \mathrm{~g} /$ ha diluted in vegetable oil.

The results showed also that, $50 \mathrm{~g} / \mathrm{ha}$ dose (diluted in diesel) of $\mathrm{M}$. anisopliae var. acridium (Green Muscle ${ }^{\circledR}$ ) resulted in an optimal mortality of locust under the cages during 3rd week ( 21 days), followed by $50 \mathrm{~g} / \mathrm{ha}$ dose (diluted in vegetable oil), respectively. From the economical point of view, use of diesel for dilution may be more practical than vegetable oil. 
Also. the efficacy of M. anisopliae var. acridium may be greater against nymphal instars (smaller size) than the adult insects (biger size) and may be related to increased susceptibility to the pathogen. Likewise, the effect of the fungus was also greater against young nymphal instars than the older ones.

The efficacy of M. anisopliae var. acridium, in all treatments, indicated that it is a specific bio-pesticide for controlling Acrididae pests but it seems to be slow acting as a bio-agent unlike chemical pesticides.

The pests may be infected by: 1) Direct impact, by droplets; 2) Secondary pickup, from vegetation and soil; 3) Horizontal transmission, by recycling the spores produced on infected cadavers.

At field application rates, M. anisopliae var. acridium is considered safe to non-target Hymenoptera, Coleoptera and Homoptera species (Prior and Streett, 1997), and to mammals (El-Kadi et al., 1993 and Zimmermann, 1993). The fungus can be mass produced relatively easily on artificial solid substrates and when formulated in oil, can be applied under a wide range of environmental conditions using commonly available pesticide application equipment (Bateman, 1997; Bateman et al., 1998 and Langewald et al., 1997, 1999). There was no side effect of the diesel use as dilutes on viability of fungus spores, it is useful to increase the efficacy impact on the insect.

Accordingly, Green Muscle ${ }^{\circledR}$ can be useful for developing different elements of an IPM strategy, both optimizing time and place of treatment, and combining or replacing the use of chemical insecticides with the use of the fungal control agent M. anisopliae var. acridium is hypothesized to be most effective as a preventive measure whereas chemical insecticides will be most effective in curative treatments. 
J. Environ. Sci.

Institute of Environmental Studies and Research - Ain Shams University

\section{REFERENCES}

Bateman, R. (1997): The development of a mycoinsecticide for the control of locusts and grasshoppers. Outlook on Agriculture 26, 13-18.

Bateman, R. P.; O. K., Douro-Kpindou, C., Kooyman, C. Lomer; and Z. Quambama, (1998): Some observations on the dose transfer of mycoinsecticide sprays to desert locusts. Crop Protection. 17 (2): 151-158.

Bullen, F. T. (1970): A review of assessment of crop losses caused by Locusts and Grasshoppers. Proc. Int. Study conf. Curr. Probl. Acr., London, 18: 163-171.

El- Kadi. M.; L. S. Xara, P.R. De Matos, J. V. N. Da Rocha \& D. P. de Oliveira, Kadi, (1993): Effects of the entomopathogen Metarhizium anisopliae on guinea pigs and mice. Environmental Entomology, 12: 37-42.

Hunter, P. (1961): Rearing and breeding locust in the laboratory. Bull. AntiLocust. Res. Center, London, 12 p.

Johnson, D. L. and M.S. Goettel, (1993): Reduction of grasshoppers populations following field application of the fungus Beauveria bassiana. Biocontrol Science and Technology, 3: 165-175.

Krall, S. (1995): Desert locusts in Africa a disaster. Disasters, 19:1-7.

Lange, C. E. (2005): The host and geographical range of the grasshopper pathogen Paranosema (Nosema) lacustae revisited. Journal Orthoptera Research, 14: 137-141.

Langewald, J.; C., Kooyman, O., Douro-Kpindou, C. J., Lomer, A.O. Dahmoud, and H. O.Mohamed, (1997): Field treatment of desert locust (Schistocerca gregaria Forskal) hoppers in Mauritania using an oil formulation of the entomopathogenic fungus Metarhizium flavoviride. Biocontrol Science and Technology. 7 (4): 603-611. 
Langewald, J.; Z., Ouambama, A., Mamadou, R.,Peveling, I., Stolz, R., Bateman, S. Attignon, S., Blanford, S., Arthurs, and C. Lomer, (1999): Comparison of an organophosphate insecticide with a mycoinsecticide for the control of Oedaleus senegalensis Krauss (Orthoptera: Acrididae) and other Sahelian grasshoppers in the field at operational scale. Biocontrol Science and Technology, 9: $199-214$.

Lomer, C.L., R. P., Bateman, D. L., Johnson, J., Langewald, and M.B. Thomas, (2001): Biological control of locusts and grasshoppers. Annual Review of Entomology, 46: 667-702.

Pretty, J. N. (1996). Regenerating Agriculture: Policies for Sustainability and Self-reliance. Earthscan Publications Ltd., London, England, 320 pp.

Prior, C. and D. Streett, (1997): Strategies for the use of entomopathogenic agents in the biological control of locusts and grasshoppers. Memoirs of the Entomological Society of Canada 171, 5-25.

Steedman, A. (Ed.) (1990): Locust handbook. (3rd edn) chatham: Natural Resources Institute, vi + 204pp.

Tingle, C. C. D. (1996): Sprayed barriers of diflubenzuron for control of migratory locust (Locusta migratoria Capito (Sauss)) [Orthoptera: Acridide] Madagascar: Short term impact on relative abundance of terrestrial non-target invertebrates. Crop Protection, 15 (6): 579-592.

Zimmermann, G. (1993): The entomopathogenic fungus Metarhizium anisopliae and its potential as biological control agent. Pesticides Science. 37: 375-379. 


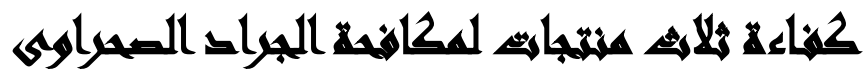

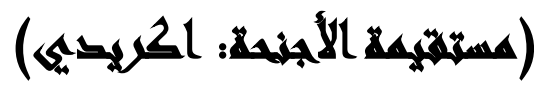

\section{[0]}

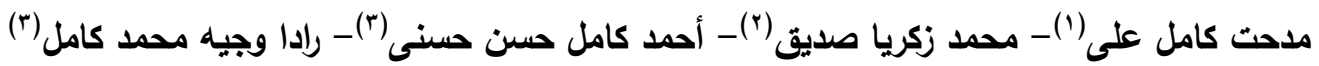

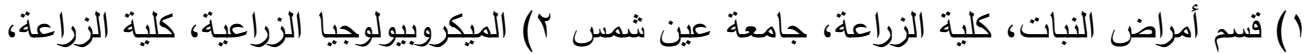

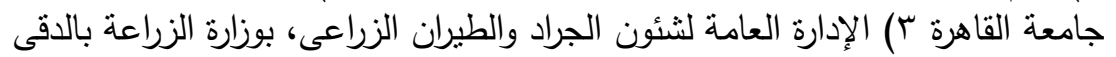

\section{المستخليس}

بعتبر الجراد الصحراوى Schistocerca gregaria (Forsk) من أخطر الآفات الحشرية

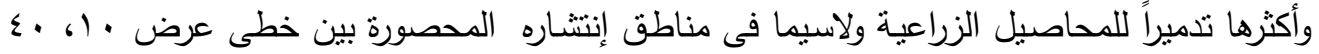

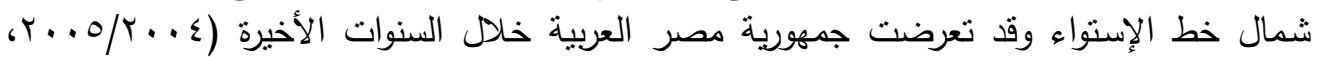

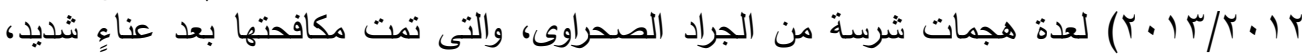

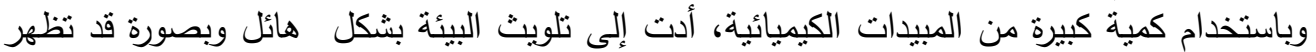

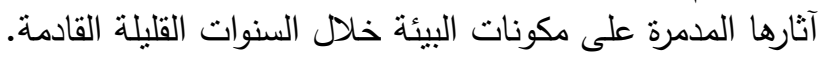

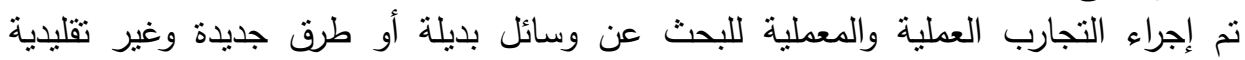

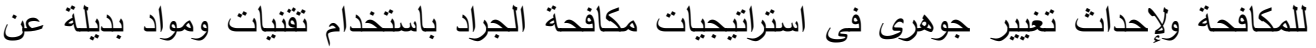

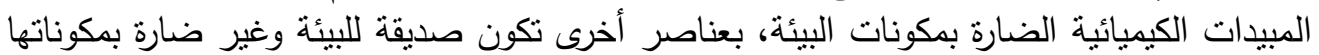
المختلفة. تتلائم مع ظروف البيئات المصرية بما يحافظ عليها ويساعد على إستثمارها والإنتفاع منها كالتالى :

Saccharopolyspora spinosa أولاً: دراسة أو تقويم تأثثير منتجات أيض بكتريا الأكتينومايسيتس

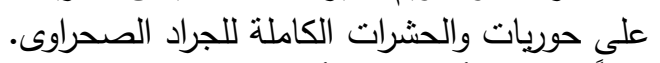

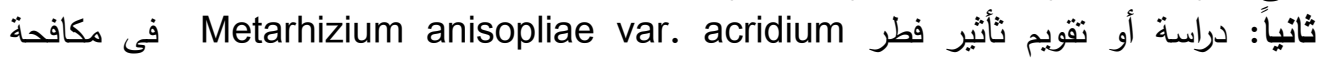
حوريات والحشرات الكاملة للجراد الصحراوى دُاني ثالثاً: دراسة أو ثقويم ثأثثر بكتريا Bacillus thuringiensis على حوريات والحشرات الكاملة للجراد

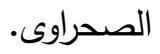
تحديد وإختيار أي من المعاملات السابقة هى الأمتل والأفضل للنطبيق وبأى جرعة.

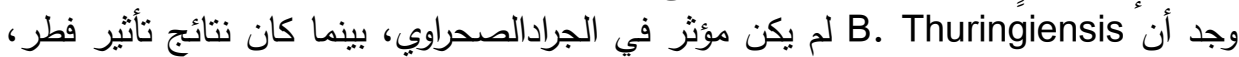
Metarhizium anisopliae var. acridium (Green Muscle*) Saccharopolyspora تأثثر بطيئ جداً ولكنه أمناً بيئياً، بينما تأثير المنتج الأيضي لبكتيريا

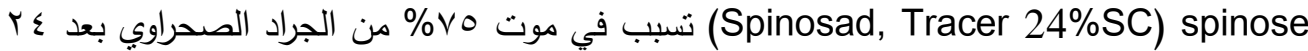

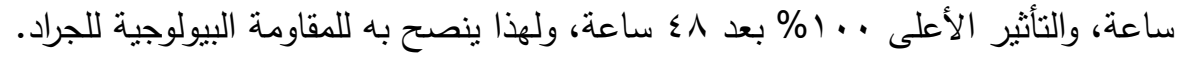

